\title{
DAYA ANTIBAKTERI SEDIAAN GEL EKSTRAK ETANOL DAUN MURBEI (Morus alba L.) SEBAGAI OBAT LUKA PADA KULIT TERHADAP Staphylococcus aureus
}

\author{
Muhammad Asri ${ }^{1}$, Fahril ${ }^{2}$ \\ ${ }^{1,2}$ Program Studi S1-Farmasi STIKes Mega Rezky Makassar \\ Email Korespondensi: Muhammadasri324@gmail.com
}

\begin{abstract}
ABSTRAK
Telah dilakukan penelitian tentang daya antibakteri sediaan gel ekstrak etanol daun murbei (Morus albaL.) sebagai obat luka pada kulit terhadap bakteri staphylococcus aureus. Untuk mengetahui daya antibakteri sediaan gel ekstrak etanol daun murbei (Morus albaL.) sebagai obat luka pada kulit terhadap Staphylococcus aureus dan Menuntukan nilai Konsentrasi Hambat Minimum (KHM). Penelitian ini merupakan penelitian eksperimental yang dilakukan di Laboratoriumuntuk menguji daya antibakteri sediaan gel ekstrak etanol daun murbei (Morus albaL.) sebagai obat luka pada kulit terhadap Staphylococcus areus. Hasil penelitian ini menunjukkan bahwa, konsentrasi $1 \%$ menghasilkan diameter rata-rata zona hambat sebesar $0,83 \mathrm{~mm}$, konsentrasi $3 \%$ sebesar $(0,97 \mathrm{~mm})$ dan konsentrasi $5 \%$ sebesar $(1,13 \mathrm{~mm})$. Dapat simpulkan bahwa; 1) Sediaan gel ekstrak etanol daun murbei pada konsentrasi 1\%, 3\% dan 5\% memiliki daya hambat yang lemah berdasarkan dari Kategori Penghambatan Antimikroba; 2) Nilai KHM yaitu konsentrasi $1 \%$ yang merupakan konsentrasi terendah yang masih memberikan efek antibakteri pada pertumbuhan bakteri Staphylococcus aureus.
\end{abstract}

Kata Kunci: Gel, Daun Murbei (Morus alba L.), Staphylococcus aureus, Konsentrasi Hambat Minimum. 


\title{
THE ANTIBACTERIAL EFFECT OF MULBERRY LEAVES (Morus alba L.) ETHANOL EXTRACT GEL AS CURE OF SKIN WOUNDS AGAINST Staphylococcus aureus
}

\begin{abstract}
A research concerning the antibacterial effect of mulberry leaves (Morusalba L.) ethanol extract gel as cure of skin wounds against Staphylococcus aureus bacteria.This research is aimed to know the antibacterial effect of mulberry leaves (Morusalba L.) ethanol extract gel as cure of skin wounds against Staphylococcus aureus bacteria and determine inhibitor concentration minimum value. It was an experimental research which conducted in the laboratory to test the antibacterial effect of mulberry leaves (Morusalba L.) ethanol extract gel as cure of skin wounds against Staphylococcus aureus bacteria.

The result of observation showed that $1 \%$ concentration produced diameter of resistance zone average as $0.83 \mathrm{~mm}, 3 \%$ concentration were $0.97 \mathrm{~mm}$ and $5 \%$ concentration were $1.13 \mathrm{~mm}$. It can be concluded that; 1) mulberry leaves ethanol extract gel stock on 1\%, 3\%, and 5\% concentration have a weak resistance based on Antimicrobial resistor category ;2) inhibitor concentration minimum value of $1 \%$ concentration, was the lowest concentration that still giving antibacterial effect to against of Staphylococcus aureus bacterial.
\end{abstract}

Keywords: Gel, Murbei leaves (Morusalba L.), Antibacterial, Staphylococcus aureus, Minimum Resistance Concentration. 


\section{PENDAHULUAN}

Kulit adalah lapisan jaringan yang terdapat pada bagian luar yang menutupi dan melindungi permukaan tubuh. Pada permukaan kulit bermuara kelenjar keringat dan kelenjar mukosa (Syaifuddin, 2006). Salah satu kerusakan kulit lainnya yaitu adanya luka. Luka adalah kerusakan kontinyuitas kulit, mukosa membran dan tulang atau organ tubuh yang lain. Ketika luka timbul, beberapa efek akan muncul seperti hilangnya seluruh atau sebagian fungsi organ, respon stress simpatis, pendarahan dan pembekuan darah, kontaminasi bakteri, dan kematian sel (Kozier, 1995). Daun murbei (Morus alba L.) merupakan salah satu tanaman yang digunakan oleh masyarakat di beberapa daerah sebagai obat bisul, luka atau borok dengan cara mengoleskan daun murbei dengan minyak kelapa kemudin di layukan diatas nyala api dan diremas-remas kemudian ditempelkan pada jaringan yang rusak. Daun murbei juga digunakan sebagai obat gigitan ular. (Herbie Tandi, 2015). Kandungan senyawa kimia pada tanaman murbei yang berkhasiat sebagai antibakteri yaitu flavanoid, ecdysterone, inokosterone, lupeol, $\beta$-sitosterol, rutin, moracetin, scopoletin, benzaldehida, eugenol, linalol, benzyl alkohol, butylamine, aseton, kholine dan quercetin (Kim et al,. 2000). Gel merupakan sistem semi padat yang terdiri dari suspensi yang dibuat dari partikel anorganik kecil atau molekul organik besar, terpenetrasi oleh suatu cairan. Jika massa gel terdiri dari jaringan partikel kecil yang terpisah, gel digolongkan sebagai sistem dua fase (misalnya Gel Aluminium Hidroksida). (Dirjen POM, 1995). Antibakteri merupakan zat yang dapat mengganggu pertumbuhan atau bahkan mematikan bakteri dengan cara mengganggu metabolisme bakteri yang merugikan. Antibakteri termasuk kedalam antimikroba yang digunakan untuk menghambat pertumbuhan bakteri.Antibakteri hanya dapat digunakan jika mempunyai sifat tosik selektif yang artinya yaitu dapat membunuh bakteri yang menyebabkan penyakit tetapi tidak beracun bagi penderitanya. (Dwidjoseputro, 2005). Pada penelitian sebelumnya (Utami, 2014) menyatakan ekstrak etanol daun murbei efektif dalam menghambat pertumbuhan bakteri Shigella dysentriaedan bakteri Staphylococcus aureus. Penelitian yang dilakukan oleh (Vincent Tee, 2015) membuktikan bahwa ekstrak etanol daun murbei mempercepat waktu penyembuhan luka insisi pada mencit Swiss Webster dengan konsentrasi $1 \%$ dan mempunyai potensi yang lebih kuat dibandingkan 
dengan povidone iodine. Berdasarkan uraian diatas, penulis melakukan pengujian daya antibakteri sediaan gel ekstrak etanol daun murbei sebagai obat luka terhadap bakteri Staphylococcus aureus.

\section{METODE PENELITIAN}

Penelitian ini merupakan penelitian deskriktif pendekatan opserparsional yaitu merode difusi agar untuk menguji daya antibakteri sediaan gel ekstrak etanol daun murbei (Morus albaL.) sebagai obat luka pada kulit terhadap Staphylococcus areus serta untuk menentukan Konsentrasi hambat minimum dilakukan pengukuran zona hambat pada medium percobaan. KHM (Konsentrasi Hambat Minimum) adalah konsentrasi minimal bahan coba yang mampu menghambat pertumbuhan bakteri setelah diinkubasi 24 jam dan tidak tumbuh koloni bakteri yang dapat diketahui dengan cara mengamati kekeruhan pada media perbenihan dengan menggunakan metode dilusi. Pengolahan data dari penelitian daya antibakteri sediaan gel ekstrak etanol daun murbei (Morus albaL.) sebagai obat luka pada kulit terhadap Staphylococcus areus menggunakan pengolahan data statistik sederhana.

Tabel 1. Formulasi sediaan gel

\begin{tabular}{l|l|c|c|c|c}
\hline \multirow{2}{*}{ Bahan } & \multirow{2}{*}{$\begin{array}{c}\text { Kegunaa } \\
\mathbf{n}\end{array}$} & \multicolumn{4}{|c}{ Konsentrasi \% } \\
\cline { 3 - 6 } & FB I & FB II & FB III & $\begin{array}{c}\text { FB } \\
\text { IV }\end{array}$ \\
\hline $\begin{array}{l}\text { Ekstrak } \\
\text { Murbei }\end{array}$ & Zat aktif & - & 1 & 3 & 5 \\
\hline Karbopol & Basis gel & 0,5 & 0,5 & 0,5 & 0,5 \\
\hline Metil paraben & Pengawet & 0,2 & 0,2 & 0,2 & 0,2 \\
\hline Propilenglikol & Kosolven & 10 & 10 & 10 & 10 \\
\hline Trietanolamin & $\begin{array}{l}\text { Pengemba } \\
\text { ng }\end{array}$ & 1 & 1 & 1 & 1 \\
\hline Gliserin & Humektan & 10 & 10 & 10 & 10 \\
\hline Air suling & $\begin{array}{l}\text { Pelarut } \\
\text { sampai }\end{array}$ & $\begin{array}{c}100 \\
\mathrm{ml}\end{array}$ & $100 \mathrm{ml}$ & $100 \mathrm{ml}$ & $\begin{array}{c}100 \\
\mathrm{ml}\end{array}$ \\
\hline
\end{tabular}

Keterangan :

a. FB I : Formula gel tanpa ekstrak

b. FB II : Formulasi gel ekstrak daun murbei $1 \%$

c. FB III : Formulasi gel ekstrak daun murbei $3 \%$

d. FB IV : Formulasi gel ekstrak daun murbei $5 \%$

\section{HASIL DAN PEMBAHASAN}

Table 2. Diameter Luas zona hambat (mm)

\begin{tabular}{c|c|c|c|c|c|c}
\hline $\begin{array}{c}\text { Konsen } \\
\text { trasi } \\
\begin{array}{c}\text { Formul } \\
\text { a Basis }\end{array}\end{array}$ & $\begin{array}{c}\text { Zona } \\
\text { Ham } \\
\text { bat } \\
\text { P1 }\end{array}$ & $\begin{array}{c}\text { Zon } \\
\text { a } \\
\text { Ham } \\
\text { bat } \\
\text { P2 }\end{array}$ & $\begin{array}{c}\text { Zon } \\
\text { a } \\
\text { Ham } \\
\text { bat } \\
\text { P3 }\end{array}$ & $\begin{array}{c}\text { Tota } \\
1\end{array}$ & $\begin{array}{c}\text { Rata } \\
\text { rata }\end{array}$ & $\begin{array}{c}\text { Keteranga } \\
\text { Hambatan } \\
\text { Hatan }\end{array}$ \\
\hline $\begin{array}{c}\text { Larutan } \\
\text { kontrol }\end{array}$ & - & - & - & - & - & $\begin{array}{c}\text { Tidak ada } \\
\text { hambatan }\end{array}$ \\
\hline $1 \%$ & 0,8 & 0,9 & 0,8 & 2,5 & 0,83 & $\begin{array}{c}\text { Hambatan } \\
\text { lemah }\end{array}$ \\
\hline $3 \%$ & 1 & 1 & 0,9 & 2,9 & 0,97 & $\begin{array}{c}\text { Hambatan } \\
\text { lemah }\end{array}$ \\
\hline $5 \%$ & 1,3 & 1 & 1,1 & 3,4 & 1,13 & $\begin{array}{c}\text { Hambatan } \\
\text { lemah }\end{array}$ \\
\hline
\end{tabular}

Keterangan :

P1 : Perlakuan Pertama

P2 : Perlakuan Kedua

P3 : Perlakuan

Data hasil penelitian diperoleh dengan cara penentuan konsentrasi hambat minimum, dapat diketahui luas zona hambat 
yang terbentuk akibat adanya pemberian zatzat antibakteri pada medium yang telah ditanam bakteri Staphylococcus

aureus. Zona bening terbentuk karena pertumbuhan Staphylococcus

aureus

terhambat. Penelitian ini dilaksanakan dengan menggunakan

bakteri Staphylococcus aureus yang diberi perlakuan menggunakan sediaan gel ekstrak etanol daun murbei dengan konsentrasi $1 \%$, 3\%, 5\% dan larutan control, dapat dilihat semakin besar konsentrasi yang digunakan maka daya hambatnya juga semakin besar. Penentuan nilai KHM dapat dilihat dari konsentrasi terkecil dapat menghambat pertumbuhan bakteri pada medim pertumbuhan. Pada konsentrasi $1 \%$ memiliki daya hambat yang rendah dengan diameter 0,83mm karena memgandung konsentrasi yang rendah padah sediaan gel. Pada konsentrasi 3\% memiliki daya hambat yang tidak jauh berbeda dibandingkan dengan konsentrasi $1 \%$ dengan diameter0,97mm. Pada konsentrasi 5\% memiliki daya hambat yang cukup tinggi dibandingkan dengan konsentrasi $1 \%$ dan 3\%. Dapat dilihat semakin besar konsentrasi yang digunakan maka daya hambatnya juga semakin besar. Menurut Pendapat Pelczar (2005: 457), bahwa peluang untuk mengenai suatu sasaran yang harus sebanding tidak hanya terhadap jumlah zat tetapi juga terhadap jumlah sasaran, semakin tinggi jumlah konsentrasi yang kita berikan dalam suatu waktu tertentu, maka semakin banyak bakteri yang mati. Lemahnya zona hambat yang dihasilkan selain dari tingkat konsentrasi, disebabkan juga bahan tambahan pada sediaan gel ekstrak etanol daun murbei. Pelczar dan Chan (1988) mengatakan adanya bahan organik dan anorganik lain dapat menurunkan dengan nyata keefektifan zat kimia antimikroba dengan cara menginaktifkan bahan-bahan tersebut.

Tabel 3. Kategori Penghambatan Antimikroba Berdasarkan Diameter Zona Hambat. Pan, Chen, Wu, Thang dan Zhao (2009).

\begin{tabular}{cc}
\hline Diameter $(\mathbf{m m})$ & $\begin{array}{c}\text { Respon Hambatan } \\
\text { Pertumbuhan }\end{array}$ \\
\hline $0-3 \mathrm{~mm}$ & Lemah \\
3-6 mm & Sedang \\
Lebih dari $6 \mathrm{~mm}$ & Kuat \\
\hline
\end{tabular}

Dari tabel diatas dapat dilihat bahwa sediaan gel ekstrak etanol dengan konsentrasi 1\%, 3\% dan 5\% memiliki daya antibakteri, tetapi respon hambatanya lemah.Diperlukan lagi konsentrasi yang lebih tinggi dalam bentuk sediaan untuk penelitian selanjutnya. Daya hambat suatu senyawa sangat berpengaruh pada konsentrasi yang 
diberikan. Menurut Pelczar (2005), bahwa sebelum suatu antibakteri digunakan untuk keperluan pengobatan, maka perlu terlebih dahulu antibakteri di uji efeknya terhadap spesies bakteri tertentu. Kemampuan antibakteri dapat ditentukan dengan mengamati konsentrasi terendah antibakteri yang masih mampu mematikan atau menghambat pertumbuhan mikroorganisme. Semakin tinggi konsentrasi senyawa antibakteri, maka daya hambatnya semakin besar. Demikian pula sebaliknya, semakin rendah konsentrasi senyawa antibakteri, maka semakin kecil pula daya hambatnya. Konsentrasi terendah yang masih mampu menunjukkan daya hambat disebut sebagai Konsentrasi Hambat Minimum (KHM). Perbedaan nilai KHM pada konsentrasi $1 \%$, $3 \%$ dan 5\% disebabkan diduga karena bakteri gram positif lebih rentan terhadap senyawa antimikroba. Menurut Pendapat Suriwiria (1999), Lapisan polisakarida pada bakteri gram negatif berfungsi sebagai penghalang terhadap masuknya beberapa macam substansi, termasuk senyawa antimikroba. Sedangkan bakteri gram positif tidak mengandung lapisan polisakarida ternyata lebih peka terhadap sejumlah senyawa antimikrobia. Menurut Pendapat Pelczar (2005) yang menyatakan Staphylococus aureus merupakan bakteri yang bersifat gram positif. Staphylococcus aureusmerupakan bakteri Gram positif berbentuk bulat berdiameter 0,7-1,2 $\mu \mathrm{m}$, tersusun dalam kelompok-kelompok yang tidak teratur seperti buah anggur, fakultatif anaerob, tidak membentuk spora, dan tidak bergerak. Berdasarkan data yang dihasilkan bahwa sediaan gel ekstrak etanol daun murbei memiliki daya antibakteri yang dapat dilihat dari nilai KHM zona hambat bening yang dihasilkan diameter rata-rata $0,83 \mathrm{~mm}$. (Menurut Pelczar 2005), ada beberapa faktor yang dapat mempengaruhi kerja antimikroba, yaitu konsentrasi atau intensitas zat antimikroba, jumlah organisme, suhu, spesies mikrooganisme, kemasaman/kebasaan $(\mathrm{pH})$, ada tidaknya bahan organik dalam desinfektan mikroorganisme.

\section{KESIMPULAN}

Sediaan gel ekstrak etanol daun murbei (Morus alba L.) memiliki daya hambat antibakteri dengan zona hambat diameter rata-rata pada konsentrasi $1 \%$ sebesar 0.83 $\mathrm{mm}$, konsentrasi $3 \%$ sebesar $0.97 \mathrm{~mm}$, pada konsentrasi $5 \%$ sebesar $1.13 \mathrm{~mm}$ yaitu dinyatakan kategori daya hambat lemah. Nilai konsentasi hambat minimum (KHM) yaitu konsentrasi $1 \%$ dengan diameter zona hambat rata-rata $0.83 \mathrm{~mm}$, 


\section{DAFTAR PUSTAKA}

Allen, V. Lotyd, dkk.2014. Bentuk Sediaan

Farmasetis \& Sistem Penghantar Obat.Edisi 9.Penerbit buku

Kedokteran EGC. Jakarta.

Badan POM. Departemen Kesehatan Republik Indonesia.2014. Buku Informatorium Obat Nasional Indonesia (IONI).Jakarta: departemen Kesehatan RI.

Bryant, Ruth. 2007. Acute \& Chronic Wounds; Current Manangement Concept Philadelphia : Mosby Elsevier.

Cleve R Susanto, G A Made Ari M. 2013.Penyakit Kulit Dan Kelamin. Nuha Medika. Jakarta

Capuccino, J., Natalie S., 2007. Microbiology : A laboratory manual, 8th edition. SanFrancisco.

Dirjen POM. Departemen Kesehatan Republik Indonesia. 1995. Farmakope Indonesia. Edisi IV. Jakarta: Departemen Kesehatan Republik Indonesia.

Ditjen POM. 2000. Parameter Standar Umum Ekstrak Tumbuhan Obat. Cetakan Pertama. Jakarta: Departemen Kesehatan Republik Indonesia.

Dwidjoseputro. 2005. Dasar-dasar Mikrobiologi. Percetakan Imagraph. Jakarta .
Gennaro R Alfaonso. 1990. Remingto's Pharmaceutical science $18^{\text {th }}$ edition book 2. Mack Publishing Company. USA.

Hariana, A. 2008. Tumbuhan Obat dan Khasiatnya. Cetakan Kelima. Penebar Swadaya. Jakarta

Herbie, Tandi. 2015. Kitab Tanaman Berkhasiat Obat-226 Tumbuhan Obat untuk Penyembuhan Penyakit dan Kebugaran Tubuh. Yogyakarta: Octopus Publishing House

Jawetz, dkk. 2005. Mikrobiologi Kedokteran / Geo F Brooks, Janet S Butel, dan Stephen A Morse. Salemba Medika. Jakarta

Kim S. Y., Gao J. J., Kang H. K., 2000, Two flavonoids from the leaves of Morus alba induce differentiation of the human promyelocytic leukemia (HL60) cell line. Biol Pharm Bull.

Kozier. 1995. Fundamental of Nursing Concept Proses and Practise. California: Addison - Wesley Publishing Company. Inc

Lieberman, Herbert A,. Martin M.R., Gilbers., 1996. Pharmaceutical Dossage Form Disperse System, Vol II. Maceal Dekker Inc. New York.

Moore, KL. 2002. Anatomi Klinis Dasar. Jakarta: Hipokrates.

Morisson, M. J. 2004. Manajemen Luka. Penerbit Buku Kedokteran. Jakarta : EGC. 
O'Leary. 2007. The Physiologic Basis of Surgery. Philadelphia : Lippincort Company.

Pelczar, M.J ; and E.C.S. Chan. 2005. Dasar-dasar Mikrobiologi. Jilid II. Jakarta: UI -Press

Pelczar, M.J.\& Chan, E.C.S. 1986. Dasardasar Mikribiologi.Jilid I. Hadioetomo, R. S, Tjitrosomo, S.S, Angka, S.L \& Imas, T. Penerbit UI Press. Jakarta.

Potter, P. A, Perry, A. G. 2006.Buku Ajar Fundamental Keperawatan.Jilid I. Jakarta: EGC.

Pan, X., F. Chen, T. Wu, H. Tang and Z. Zhao. 2009. The Acid, Bile Tolerance and Antimicrobial Property of Lactobacillus acidophilus NIT. J. Food Control.

Samsijah dan L. Andadari. 1992. Petunjuk Teknis Budidaya Murbei (Morus $s p$ ).Pusat Penelitian dan Pengembangan Hutan dan Konservasi Alam, Bogor.

Suriawiria, U. 1999. Mikrobiologi. Jakarta : Universitas Terbuka.

Syaifuddin, H., 2006. Anatomi dan Fisiologi Untuk Mahasiswa Keperawatan.Edisi 3.Penerbit Buku Kedokteran EGC, Jakarta.

Utami S.H, Anggia O, Henny N.K. 2014. Jurnal Penelitian "Daya Antibakteri Ekstrak Daun Dan Buah Murbei (Morus alba L.)Terhadap Staphylococcus aureus Dan Shigella
dysenteriae".Biologi FMIPA UNM, Malang - Indonesia.

Vincent T, Sugiarto P. 2015. Jurnal Penelitian "Pengaruh Ekstrak Etanol Daun Murbei (Morus alba L.)Terhadap Durasi Penyembuhan Luka Insisi Pada Mencit Swiss Webster".Fakultas Kedokteran, Universitas Kristen Maranatha, Bandung, Indonesia.

Wiley. 2008. Pharmaceutical Maufacturing Handbook, Production and Process. Canada.

Yati H. I., Vincent H.S., 2008. Penisilin, Sefalosporin dan Antibiotik Betalaktam lainnya dalam Farmakologi dan Terapi, Edition 5. Jakarta. 